\title{
The natural history of congenital myotonic dystrophy: mortality and long term clinical aspects
}

University of Wales College of Medicine, Cardiff,

Institute of

Medical Genetics

W Reardon

I Fenton

P S Harper

Department of Medical

Statistics and Computing

$R$ Newcombe

Department of

Child Health,

University of Wales

College of Medicine

Community Health Unit,

Lansdowne Hospital,

Cardiff

J Sibert

Correspondence to

Dr W Reardon,

Mothercare Unit of

Clinical Genetics and

Fetal Medicine

Institute of Child Health,

30 Guilford Street,

London WCIN IËH.

Accepted 16 September 1992

\author{
W Reardon, R Newcombe, I Fenton, J Sibert, P S Harper
}

\begin{abstract}
Although the genetic basis of the congenital form of myotonic dystrophy has recently been clarified, data as to outcome in terms of life expectancy and morbidity are scanty. Life table data based on a cohort of 115 patients with a confirmed diagnosis of congenital myotonic dystrophy are presented. The data suggest a $25 \%$ chance of death before 18 months of age and a $50 \%$ chance of survival into the mid-30s. The profile of disease and complications among survivors is also charted.
\end{abstract}

(Arch Dis Child 1993;68:177-81)

Myotonic dystrophy in early childhood was first recognised by Vanier, who correctly identified the patient's problems as dating from birth. ${ }^{1}$ This observation has subsequently been confirmed by several authors and the principal clinical features defined. ${ }^{2-4}$ Foremost among these are hypotonia with facial weakness, talipes, neonatal respiratory distress, and feeding problems attributed to palatal weakness and pharyngeal incoordination. ${ }^{5}$ The condition may be suspected prenatally because of polyhydramnios or reduced fetal movement in pregnancy, thought to reflect intrauterine hypotonia. ${ }^{5}$

Delayed motor development and mental retardation have been observed in approximately two thirds of patients and the significant effects of these factors on requirements for special education in this group of patients have been documented. ${ }^{56}$ Data documenting long term outcome of patients with this disorder as they reach adult life are deficient, as are data on mortality, cause of death, and life expectancy. Long term medical complications among congenitally affected patients with myotonic dystrophy have only been a feature of one study. ${ }^{6}$ This involved 42 patients, most of whom (27/42) were 18 years or under at the time. Apart from the expected motor disturbances, the main factors to emerge were the high incidence of audiological and non-specific gastrointestinal complaints and the relatively low incidence of lens opacities and cataract, given the known significant association of lens changes and myotonic dystrophy in the classical form. More recently the association of disordered anal tone and myotonic dystrophy, both in the congenital and classical forms, has been emphasised. $^{78}$

Death in the neonatal period is now well recognised, most commonly due to failure to establish respiration. Harper noted a significant excess of infant mortality among the siblings of his cases, ${ }^{3}$ two thirds of which occurred in the first 24 hours of life. Although many of these infants died without a diagnosis of congenital myotonic dystrophy being recognised, retrospective evidence of this likely diagnosis was available in many instances. ${ }^{3}$ Intensive care management has altered the care of congenitally affected children with respiratory problems, but this complication is still associated with a significant mortality, particularly if ventilation is required for more than four weeks. ${ }^{9}$

Myotonic dystrophy is an autosomal dominant condition and the genetic basis has recently been elucidated. ${ }^{10-13}$ The molecular defect has been traced to an unstable DNA triplet (CTG) sequence at the $3^{\prime}$ untranslated end of the gene on the long arm of chromosome 19, which is expanded in myotonic dystrophy. Preliminary data suggest a relationship between the expansion of the unstable sequence and the degree of clinical manifestation of the disorder, with congenitally affected patients having a grossly expanded DNA region of the order of 3-6 kilobases. ${ }^{14}$

Although this offers an explanation for why congenital myotonic dystrophy differs clinically from the classical adult form, it does not readily explain the observation that the gene transmitting parent in almost all congenitally affected patients is the mother. ${ }^{5}$ It has been speculated that this differential transmission is due to an unidentified intrauterine factor or genomic imprinting effects, ${ }^{51516}$ although positive proof of this is currently deficient. In view of the deficiency of data on long term outcome in congenital myotonic dystrophy we have attempted to obtain follow up data on a cohort of patients with the condition and have constructed a life table based thereon. Additionally, information as to cause of death, morbidity, clinical complications, and other observations on congenital myotonic dystrophy is presented.

\section{Patients and methods}

Data were obtained on 115 patients (65 males and 50 females) born between 1 January 1940 and 31 December 1989, all of whom had had a diagnosis of congenital myotonic dystrophy made in their lifetime. These patients were identified through the 400 families with myotonic dystrophy known to the Institute of Medical Genetics and would be expected to represent an unbiased sample of patients with the congenital form of the disease. Seventy one patients were living at the time of commencing the study. Forty two of these were examined personally and information on the remaining 29 
Table 1 Three life tables of survival in congenital myotonic dystrophy. Probabilities of survival to age $X$, calculated using basis 1 , basis 2, and basis 3 (see text for details)

\begin{tabular}{|c|c|c|c|}
\hline Age $X$ & Basis I & Basis 2 & Basis 3 \\
\hline 0 & 1.000 & 1.000 & \\
\hline $\begin{array}{l}\text { Days: } \\
1 \\
2 \\
3 \\
7 \\
10 \\
12 \\
20 \\
21\end{array}$ & $\begin{array}{l}0.922 \\
0.887 \\
0.878 \\
0.861 \\
0.861 \\
0.843 \\
0.835 \\
0.826\end{array}$ & $\begin{array}{l}0.833 \\
0.790 \\
0.768 \\
0.754 \\
0.746 \\
0.732 \\
0.725 \\
0.710\end{array}$ & \\
\hline $\begin{array}{l}\text { Months: } \\
1 \\
2 \\
3 \\
4 \\
7 \\
12 \\
14 \\
16 \\
88 \\
186 \\
195 \\
222 \\
223 \\
234 \\
240 \\
249 \\
274 \\
304 \\
315 \\
388 \\
462 \\
474 \\
486\end{array}$ & $\begin{array}{l}0 \cdot 807 \\
0 \cdot 791 \\
0 \cdot 791 \\
0 \cdot 774 \\
0 \cdot 765 \\
0 \cdot 765 \\
0 \cdot 757 \\
0 \cdot 745 \\
0 \cdot 737 \\
0 \cdot 724 \\
0 \cdot 711 \\
0 \cdot 698 \\
0 \cdot 685 \\
0 \cdot 671 \\
0 \cdot 657 \\
0 \cdot 643 \\
0 \cdot 625 \\
0 \cdot 598 \\
0 \cdot 564 \\
0 \cdot 508 \\
0 \cdot 339 \\
0 \cdot 169 \\
0\end{array}$ & $\begin{array}{l}0.688 \\
0.667 \\
0.659 \\
0.645 \\
0.638 \\
0.638 \\
0.630 \\
0.623 \\
0.614 \\
0.604 \\
0.593 \\
0.582 \\
0.571 \\
0.560 \\
0.548 \\
0.536 \\
0.521 \\
0.498 \\
0.470 \\
0.423 \\
0.282 \\
0.141 \\
0\end{array}$ & $\begin{array}{l}1.000 \\
0.989 \\
0.977 \\
0.964 \\
0.947 \\
0.930 \\
0.912 \\
0.895 \\
0.877 \\
0.859 \\
0.840 \\
0.816 \\
0.781 \\
0.738 \\
0.663 \\
0.443 \\
0.221 \\
0\end{array}$ \\
\hline
\end{tabular}

Table 2 Log rank analyses for survival by gender and birth cohort. Basis 1: "probable congenital myotonic dystrophy' deaths omitted

\begin{tabular}{|c|c|c|c|}
\hline & $\begin{array}{l}\text { Observed } \\
\text { deaths }\end{array}$ & $\begin{array}{l}\text { Expected } \\
\text { deaths }\end{array}$ & Observed/expected \\
\hline $\begin{array}{l}\text { Male } \\
\text { Female }\end{array}$ & $\begin{array}{l}23 \\
21\end{array}$ & $\begin{array}{l}23 \cdot 101 \\
20 \cdot 899\end{array}$ & $\left.\begin{array}{l}1.00 \\
1.00\end{array}\right\} \chi^{2}=0.001(\mathrm{df}=1), p=0.98$ \\
\hline $\begin{array}{l}1940-49 \\
1950-59 \\
1960-69 \\
1970-79 \\
1980-89\end{array}$ & $\begin{array}{r}4 \\
5 \\
9 \\
11 \\
15\end{array}$ & $\begin{array}{r}5 \cdot 379 \\
7 \cdot 254 \\
12 \cdot 527 \\
9 \cdot 226 \\
9 \cdot 613\end{array}$ & $\left.\begin{array}{l}0.74 \\
0.69 \\
0.72 \\
1.19 \\
1.56\end{array}\right\} \chi^{2}=5.41 \quad(\mathrm{df}=4)$ \\
\hline $\begin{array}{l}1940-69 \\
1970-89\end{array}$ & $\begin{array}{l}18 \\
26\end{array}$ & $\begin{array}{l}25 \cdot 160 \\
18 \cdot 839\end{array}$ & $\left.\begin{array}{l}0.72 \\
1.38\end{array}\right\} \chi^{2}=4.760(\mathrm{df}=1), \mathbf{p}=0.029$ \\
\hline
\end{tabular}

Table 3 Log rank analyses for survival by gender and birth cohort. Basis 2: 'probable congenital myotonic deaths' included

\begin{tabular}{|c|c|c|c|c|}
\hline & $\begin{array}{l}\text { Observed } \\
\text { deaths }\end{array}$ & $\begin{array}{l}\text { Expected } \\
\text { deaths }\end{array}$ & \multicolumn{2}{|c|}{ Observed/expected } \\
\hline $\begin{array}{l}\text { Male } \\
\text { Female }\end{array}$ & $\begin{array}{l}36 \\
31\end{array}$ & $\begin{array}{l}36 \cdot 241 \\
30 \cdot 759\end{array}$ & $\left.\begin{array}{l}0.99 \\
1.01\end{array}\right\}$ & $\chi^{2}=0.003(d \mathbf{d}=1), \mathbf{p}=0.95$ \\
\hline $\begin{array}{l}1940-49 \\
1950-59 \\
1960-69 \\
1970-79 \\
1980-89\end{array}$ & $\begin{array}{r}4 \\
7 \\
15 \\
15 \\
26\end{array}$ & $\begin{array}{r}6 \cdot 051 \\
9 \cdot 760 \\
18 \cdot 325 \\
14 \cdot 753 \\
18 \cdot 111\end{array}$ & $\left.\begin{array}{l}0.66 \\
0.72 \\
0.82 \\
1.02 \\
1.44\end{array}\right\}$ & $\chi^{2}=5 \cdot 520(\mathrm{df}=4)$ \\
\hline $\begin{array}{l}1940-69 \\
1970-89\end{array}$ & $\begin{array}{l}26 \\
41\end{array}$ & $\begin{array}{l}34 \cdot 136 \\
32 \cdot 864\end{array}$ & $\begin{array}{l}0.76 \\
1.25\end{array}$ & $\chi^{2}=3.954(\mathrm{df}=1), p=0.047$ \\
\hline
\end{tabular}

Table 4. Log rank analyses for survival by gender and birth cohort. Basis 3: restricted to survivors at 12 months

\begin{tabular}{|c|c|c|c|c|}
\hline & $\begin{array}{l}\text { Observed } \\
\text { deaths }\end{array}$ & $\begin{array}{l}\text { Expected } \\
\text { deaths }\end{array}$ & Obser & ed/expected \\
\hline $\begin{array}{l}\text { Male } \\
\text { Female }\end{array}$ & $\begin{array}{l}8 \\
9\end{array}$ & $\begin{array}{l}8 \cdot 118 \\
8 \cdot 881\end{array}$ & $\begin{array}{l}0.99 \\
1.01\end{array}$ & $\chi^{2}=0.003(\mathrm{df}=1), p=0.95$ \\
\hline $\begin{array}{l}1940-49 \\
1950-59 \\
1960-69 \\
1970-79 \\
1980-89\end{array}$ & $\begin{array}{l}4 \\
4 \\
6 \\
1 \\
2\end{array}$ & $\begin{array}{l}4 \cdot 329 \\
3.991 \\
5 \cdot 472 \\
2 \cdot 497 \\
0 \cdot 709\end{array}$ & $\begin{array}{l}0.92 \\
1.00 \\
1 \cdot 10 \\
0 \cdot 40 \\
2 \cdot 82\end{array}$ & $\chi^{2}=3 \cdot 322(\mathrm{df}=4)$ \\
\hline $\begin{array}{l}1940-69 \\
1970-89\end{array}$ & $\begin{array}{r}14 \\
3\end{array}$ & $\begin{array}{r}13 \cdot 793 \\
3 \cdot 206\end{array}$ & $\begin{array}{l}1.02 \\
0.94\end{array}$ & $\chi^{2}=0.016(d f=1), p=0.9$ \\
\hline
\end{tabular}

were furnished by clinical colleagues in other centres. Forty four patients had died by the time of surveying in March 1992. Documentary evidence on cause of death and age at death was sought in all cases. Survival durations of the remaining 71 were 'censored' at the age attained at the time of the study in March 1992. The family files of these 115 index cases were also studied and a further 23 dead siblings ( 13 males and 10 females) identified who satisfied at least one major criterion for the diagnosis of congenital myotonic dystrophy. This diagnosis had not been recorded in their lifetimes and no organic cause of death identified. For the purpose of this study this group of patients have been termed 'probable' congenital myotonic dystrophy.

\section{Results}

SURVIVAL

Table 1 gives life tables expressing the survival of these subjects. The time scale has been expressed as completed months; days, if under one month; and one day if less than 24 hours. The second column gives survival probabilities as from birth, calculated using basis 1 : only data from the 115 definite cases of congenital myotonic dystrophy are included. As ages are rounded down, the figure of 0.807 for one month survival denotes the estimated probability of surviving to the end of that month, that is, to just under 2 months of age. The estimated survival probabilities for ages not shown in the table are the same as those for the previous age specified, for example, for 5 and 6 months the survival probabilities are estimated to be $0 \cdot 774$. The survival probability decreases only at those ages at which a death occurs.

The third column gives a similar life table calculated by basis 2 ; including the probable cases of congenital myotonic dystrophy. The fourth column gives probabilities of survival, conditional upon reaching 1 year of age (basis 3 ). These figures are unaffected by whether probable cases are regarded as having the condition or not.

Table 2 presents log rank analyses comparing survival between genders and between birth cohorts, based on the definite cases only. A total of 44 of 115 died; the expected deaths are obtained by sharing out the subgroups in such a way as to take into account the numbers at risk in each subgroup, the periods for which they were at risk, and the current mortality rates in the whole cohort. Table 3 gives corresponding analyses for basis 2: deaths due to probable cases of congenital myotonic dystrophy are now included and 67 of 138 died. In table 4 data are considered only in relation to those surviving 12 months.

\section{CLINICAL}

Pregnancy ranged from 32 to 46 completed weeks with a mean of $39 \cdot 3$. In 43 of the 115 definite cases $(37 \%)$ and 10 of the 23 probable cases $(43 \%)$ it was complicated by polyhydramnios. Table 5 presents data as to mode of delivery of the 115 definite cases. 
Fifty eight (50\%) had talipes, bilateral in 52 and unilateral in six. Information on age at sitting independently was available for 59 patients. This ranged from 7 to 24 months, mean $12 \cdot 4$. Information on age at walking was available on 69 cases and are presented by talipes status in table 6 . Three $(4 \%)$ of the 71 living patients required wheelchair assistance in the third decade of life.

Mental development was difficult to assess. In many instances formal testing had never been performed and in those patients $(n=17)$ for whom such a result was available, no uniform method of testing had been employed and results were not comparable. Of those who attended school $(n=78), 19(24 \cdot 4 \%)$ went to a mainstream school while the remainder required special education. Even in the normal school situation 14 of these 19 required further assistance in order to achieve minimum standards in reading and counting. Writing was universally poor. Eight patients out of 48 reaching the age of 20 years were in full time employment (table 7) and two were housewives coping poorly and were heavily dependent on support services.

Causes of death are documented in table 8. Among the 71 surviving patients, a variety

Table 5 Mode of delivery

\begin{tabular}{ll}
\hline & No (\%) of patients \\
\hline Vaginal delivery, vertex presentation & $94(82)$ \\
Induced post-term & $8(7)$ \\
Caesarean section for fetal distress & $7(6)$ \\
Breech presentation & $2(2)$ \\
Forceps/assisted delivery & $4(3)$ \\
\hline
\end{tabular}

Table 6 Mean age of walking, compared between those with and without talipes

\begin{tabular}{lll}
\hline & No & $\begin{array}{l}\text { Mean age at } \\
\text { walking (months) }\end{array}$ \\
\hline Talipes & 43 & $29 \cdot 1$ \\
No talipes & 26 & $23 \cdot 4$ \\
Total & 69 & $27 \cdot 1$ \\
\hline
\end{tabular}

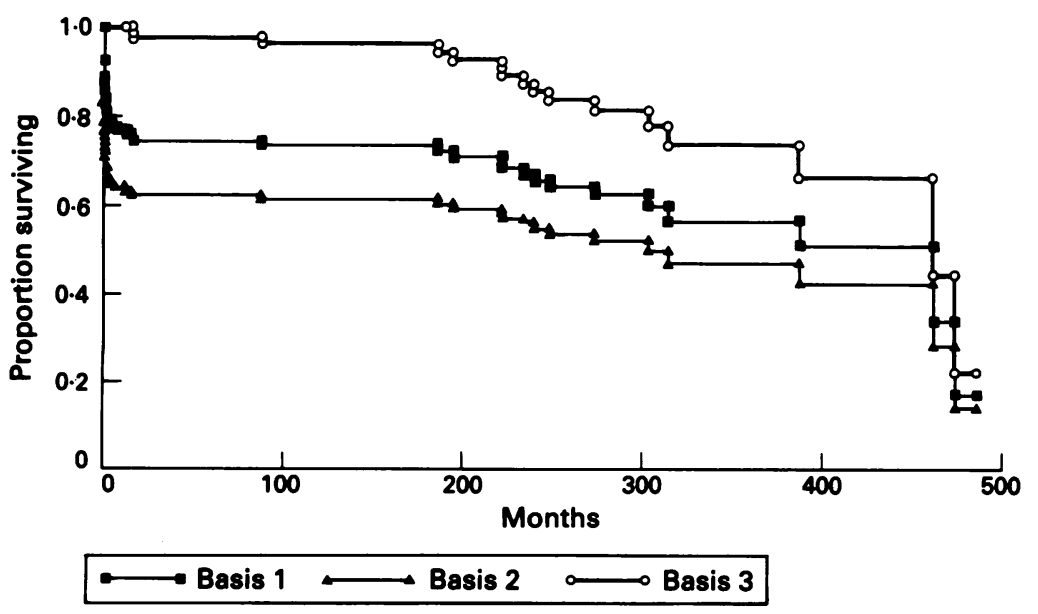

Life tables for survival in congenital myotonic dystrophy. The curves are plotted for the life tables produced under the three options considered in table 1 . of chronic clinical problems were identified (table 9). Although these data are presented as percentages, the complications to which the table refers are not mutually exclusive as some patients had more than one problem. Moreover these data relate to the 71 survivors, some of whom were very young at the time of study and some of the deceased cases may have had similar problems.

Parallel with the delay in motor development, toilet training was delayed in several surviving patients. Ten (15\%) of 66 patients with adequate information were still incontinent of faeces at the age of 5 years and one third had chronic problems in establishing a regular bowel habit. Of the 42 patients examined personally (WR), evidence of reflex anal dilatation was sought in 30 and found to be present in 22 (73\%).

Follow up arrangements for patients were highly variable. Twenty six of the 71 survivors (37\%) were in receipt of hospital physician/ paediatrician review at intervals ranging from 3-18 months. In only seven (10\%) cases had an electrocardiographic (ECG) examination been performed within the previous 18 months.

In all 115 cases the gene transmitting parent was female. Evidence as to the sex of the gene transmitting grandparent showed an apparent excess of cases where the grandfather was the gene carrier (table 10). There was no instance of a congenitally affected patient having children in this series, where 48 patients reached 20 years and 12 reached 30 .

Table 7 Details of current employment among the 48 patients reaching 20 years of age

\begin{tabular}{lc}
\hline Employment & No of patients \\
\hline Local government clerical officer & 1 \\
Cinema attendant & 1 \\
Garden centre operative & 1 \\
In adult training workshop & 5 \\
Housewife & 2 \\
Unemployed & 38 \\
Total & 48 \\
\hline
\end{tabular}

Table 8 Causes of death $(n=44)$

\begin{tabular}{lc}
\hline Cause & No of deaths \\
\hline Respiratory & 29 \\
Cardiac arrhythmias & 2 \\
Non-specific cardiomyopathy & 1 \\
Anaesthetic accidents & 3 \\
Sudden unexplained & 6 \\
Pulmonary embolus & 2 \\
Unknown & 1 \\
\hline
\end{tabular}

Table 9 Chronic medical problems in surviving patients $(n=71)$

\begin{tabular}{ll}
\hline Problem & No (\%) surviving \\
\hline Constipation/diarrhoea & $24(34)$ \\
Recurrent otitis & $15(21)$ \\
Scoliosis & $7(10)$ \\
Cataract/proved lens opacity & $5(7)$ \\
Cardiac rhythm disturbance & $3(4)$ \\
Vesicoureteric reflux & $1(1)$ \\
\hline
\end{tabular}


Table 10 Sex of gene transmitting grandparent $(n=115)$

\begin{tabular}{ll}
\hline & No (\%) \\
\hline Grandfather & $45(39)$ \\
Grandmother & $25(21)$ \\
Unknown & $45(39)$ \\
\hline
\end{tabular}

\section{Discussion}

Restricting attention to definite cases of congenital myotonic dystrophy (basis 1), 25\% die within 18 months, mainly in the neonatal period, as a result of respiratory complications. Very few deaths then occur until the late teenage years. The figures (table 1) suggest that half the subjects would survive to their mid-30s, but then die before reaching 41 . This precipitous fall in survival probability around $\mathbf{4 0}$ years is because only three individuals were studied to such an age and all died at that age band. The degree of precision of estimated survival probabilities at the far end of a life table is recognised to be extremely poor.

Inevitably basis 2 , in which the probable cases who had already died are included in addition to the definite cases, leads to a less optimistic assessment of survival probability. The last of the probable cases died at 3 months and thereafter the curve expressing this premise runs parallel to that expressing basis 1 (figure). The results from basis 3 calculations are unaffected by probable case ascertainment. Again this leads to a curve parallel to that generated by basis 1 and basis 2 (figure).

Differences in mortality between males and females are negligible in these data. A comparison of the five decades of birth using a $4 \mathrm{df}$ (degrees of freedom) test does not reach statistical significance. It is clear that this approach is not sensitive to the trend that is clearly indicated by the relative risk figures (table 2 ). If the patients are divided into two groups, born before and after 1970, then a significant difference is revealed (table 2, $p=0.029$ ) with a higher mortality in the recent cohorts. This suggests that more complete information on early deaths in the last 20 years swamps any prospect of seeing the possible benefits of improved neonatal management over that period. The conclusions from table 3 with regard to those cohorts born before and after 1970 reiterate this, again showing a significant $(p=0.047)$ excess of deaths in the group born after 1970.

In table 4 data are restricted to survivors at 12 months. The difference according to birth cohort (born before and after 1970) is now lost. This may reflect the smaller numbers (17 deaths out of 89 subjects) or be because the cohort differences seen in table 2 and 3 arise due to difficulties obtaining complete ascertainment of early deaths in the earlier born cohorts. It is remarkable that the ratio of probable congenital myotonic dystrophy deaths to definite congenital myotonic dystrophy deaths has actually increased-to 15 probable: 26 definite $(0.58)$ in 1970-89, eight probable: 18 definite $(0.44)$ in 1940-69. This strongly suggests that, even with inclusion of the probable cases, there is under ascertainment of deaths due to congenital myotonic dystrophy in the earlier born cohort. This observation confirms that the higher mortality in the cohort born after 1970 is biased by the incomplete information in the cohort born after 1970 .

The clinical data confirm a significant incidence $(18 \%)$ of obstetric complication in pregnancies where the baby is affected with congenital myotonic dystrophy. Likewise there is a suggestion of the importance of talipes as a factor in delaying walking (table 6). Statistically significant delay $(p=0.029)$ in age at walking exists for the talipes as compared with the nontalipes group of patients, using the MannWhitney confidence test and is confirmed by unpaired $t$ test. Whether this observation is a primary effect of the talipes or a reflection of more serious muscle weakness that might underlie the talipes in this situation is unclear.

Despite recent evidence that the cardiac complications of classical myotonic dystrophy may be predicted by annual ECG investigation, ${ }^{17}$ only $10 \%$ of patients in this series are having this investigation. None the less it is clear from table 8 and 9 that death due to cardiac dysrhythmia is also a feature of the disease in its congenital form. Indeed it is possible that as many as $20 \%(9 / 44)$ of the patients in this series died of cardiac complications if the six sudden unexplained deaths are taken into account. In view of these observations clinical practice may need to adapt to incorporate ECG as a routine part of follow up in patients with congenital myotonic dystrophy. The three deaths due to anaesthetic accidents emphasise the risks related to anaesthesia in this condition. In all three cases the diagnosis of myotonic dystrophy was known before anaesthesia but appropriate precautionary procedures were underestimated.

The widespread observation of gastrointestinal symptoms is not unexpected and probably reflects the involvement of the smooth muscle of the bowel in the disease process, resulting in abnormal anal tone and function, such as that demonstrated in the anal sphincter by the high incidence of positive anal dilatation test. Reflex anal dilatation, where the buttocks are parted for up to 30 seconds and the anus is seen to dilate is a physical sign that has been suggested to be diagnostic of sexual abuse. The consensus appears to be that, although it may be a feature of recent anal abuse, it is by no means diagnostic of this condition and may be found in other situations, such as constipation. ${ }^{18}$ This study confirms that reflex anal dilatation is commonly found in congenital myotonic dystrophy without other evidence of sexual abuse. This observation emphasises that additional care needs to be taken in interpreting anal physical signs in the context of possible sexual abuse in children with muscle disease. ${ }^{7}$

Maternal transmission of the gene was observed in all cases in the study. An apparent excess of grandfathers among the grandparental gene transmitters has been noted by others. ${ }^{19}$ A similar observation might also apply in this survey (table 10), although this cannot be substantiated owing to the high proportion of cases where the grandparental gene transimitter was unknown.

We wish to thank all colleagues who assisted us in this study by providing clinical information and/or access to patients, in particular J Burn, J Goodship, P Turnpenny, A Johnstone, P Farndon, D Gardner-Medwin, S Green, R Mueller, J Tolmie, E Maher, C Garrett, S Huson, M Patton, D Donnai, V Dubowitz, $\mathbf{R}$ Winter, and M Baraitser. The work was sponsored by Muscular Dystrophy Group of Great Britain and the Wellcome Trust, and the Medical Research Council. 
1 Vanier TM. Dystrophia myotonica in childhood. $B M \mathcal{F}$ $1960 ; \mathrm{ii}: 1284-8$.

2 Dodge PR, Gamstrop I, Byers RK, Russell P. Myotonic dystrophy in infancy and childhood. Pediatrics 1966;35:319.

3 Harper PS. Congenital myotonic dystrophy in Britain. 1. Clinical aspects. Arch Dis Child 1975;50:505-13.

4 Harper PS. Congenital myotonic dystrophy in Britain. 2. Genetic basis. Arch Dis Child 1975:50:514-21.

5 Harper PS. Myotonic dystrophy. 2nd Ed. London: W B Saunders, 1989.

6 O'Brien T, Harper PS. Course, prognosis and complications of childhood-onset myotonic dystrophy. Dev Med Child Neurol 1984;26:62-7.

7 Reardon W, Hughes HE, Green SH, Lloyd Woolley V, Harper PS. Anal abnormalities in childhood myotonic dystrophy; a possible source of confusion in child sexual abuse. Arch Dis Child 1992;67:527-8.

8 Hamel R J Devroede G Arhan P. Tetreault JP, Lemieux B, Scott $\mathrm{H}$. Functional abnormalities of the anal sphincter in patients with myotonic dystrophy. Gastroenterology 1984;
86:1469-74.

9 Rutherford MA, Heckmatt JZ, Dubowitz V. Congenital myotonic dystrophy:respiratory function at birth determines survival. Arch Dis Child 1989;64:191-5.

10 Harley HG, Brook JD, Rundle SA, et al. Expansion of an unstable DNA region and phenotype variation in myotonic dystrophy. Nature 1992;355:545-6.

11 Buxton J, Shelbourne P, Davies J, et al. Detection of an unstable fragment of DNA specific to individuals with myotonic dystrophy. Nature 1992;355:547-8.

12 Aslanidis C, Jansen G, Amemiya C, et al. Cloning of the essential myotonic dystrophy region and mapping of the essential myotonic dystrophy region and
putative defect. Nature 1992;355:548-51.

13 Brook JD, McCurrach ME, Harley HG, et al. Molecular basis of myotonic dystrophy: expansion of a trinucleotide (CTG) repeat at the $3^{\prime \prime}$ end of a transcript encoding a protein kinase family member. Cell 1992;68:799-808.

14 Harley HG, Rundle SA, Reardon W, et al. Unstable DNA sequence in myotonic dystrophy. Lancet 1992;339:1125-8.

15 Hall JG. Genomic imprinting: review and relevance to human disease. Am 7 Hum Genet 1990;46:857-73.

16 Clarke A. Genetic impringing in clinical genetics. Development 1990;suppl:131-9.

17 Anonymous. The heart in myotonic dystrophy [Editorial]. Lancet 1992;339:528-9.

18 Royal College of Physicians. Physical signs of sexual abuse in children. London: Royal College of Physicians, 1991.

19 Howeler CJ, Busch HFM, Geraedts JPM, Niermeijer MF, Staal A. Anticipation in myotonic dystrophy: fact or fiction. Brain 1989;112:779-7. 